\title{
S-index and soybean root growth in different soil textural classes
}

\author{
Pedro D. de Oliveira ${ }^{1}$, Michel K. Sato ${ }^{1}$, Sueli Rodrigues ${ }^{1} \&$ Herdjania V. de Lima $^{1}$ \\ ${ }^{1}$ Universidade Federal Rural da Amazônica/Instituto de Ciências Agrárias/Área de Ciência do Solo. Belém, PA. Email: daniel.oliveira@ufra.edu.br; \\ michel.sato@ufra.edu.br; rodsueli@gmail.com; herdjania@pq.cnpq.br (Corresponding author)
}

\section{Key words:}

degree of compaction critical soil bulk density relative root length

\begin{abstract}
A B S T R A C T
This study tested the hypothesis that the limiting values of S-index, proposed in the literature can not be used to determine the degradation condition of soils under soybean cultivation in the state of Pará, Brazil. The objective was to determine limiting values of S-index using soil physical attributes and validate it with soybean root growth, in soils with different textural classes. For the experimental design, the following treatments were established: five compaction levels for sandy loam and sandy clay loam soils and three levels for clayey and very clayey soils. The following physical parameters were analysed: particle-size distribution, soil bulk density, critical soil bulk density, degree of compaction, soil-water retention curve, S-index and relative root length of soybean. The limiting values of S-index varied according to soil textural class and were equal to $0.037,0.020$ and 0.056 for sandy loam, sandy clay loam and clay, respectively. The S-index does not apply to soils with clay content $>71 \%$, because it does not vary with the degree of compaction of the soil or the root growth of the evaluated crop.
\end{abstract}

Palavras-chave:

grau de compactação densidade do solo crítica comprimento radicular relativo

\section{Índice $S$ e crescimento radicular da soja em diferentes classes texturais}

\section{R E S U M O}

Neste trabalho se testou a hipótese de que os valores limitantes do índice $\mathrm{S}$ propostos na literatura, não podem ser utilizados para determinar o nível de degradação dos solos cultivados com soja no Estado do Pará. O objetivo foi determinar os valores limitantes do índice $\mathrm{S}$ usando atributos físicos do solo e validar o crescimento radicular da cultura da soja em solos com diferentes classes texturais. Para o ensaio experimental obtiveram-se os seguintes tratamentos: cinco níveis de compactação para os solos com textura francoarenosa e franco-argiloarenosa e três níveis de compactação para a classe argilosa e muito argilosa. Foram determinadas as seguintes análises físicas: granulometria, densidade do solo, densidade do solo crítica, grau de compactação, curva de retenção de água, índice-S e o comprimento radicular relativo da cultura da soja. Concluiu-se que os valores limitantes do índice $S$ para o crescimento radicular da soja variaram com a classe textural e foram de 0,037; 0,020 e 0,056 para as classes franco-arenosa, franco-argiloarenosa e argilosa, respectivamente. $\mathrm{O}$ índice-S não se aplica a solos com conteúdo de argila $>71 \%$ por não variar com o grau de compactação nem com o crescimento radicular da cultura analisada. 


\section{INTRODUCTION}

The S-index was proposed by Dexter (2004a, b) as an indicator of soil physical quality with sensitivity to identify changes in its physical properties and, consequently, its state of degradation (Dexter, 2004a). Calculated from the slope of the soil water retention curve at its inflection point, the theory for the index is based on the fact that most soil physical properties are controlled by characteristics of its structure, which in turn is defined by the pore size distribution in the matrix.

Many authors show that S-index is a useful tool to estimate various soil physical properties, such as porosity, bulk density, resistance to root penetration, organic matter, among others. In addition, these authors suggest that $S$ values allow the direct comparison between different soils and the effects of treatments and management conditions (Dexter \& Czyz, 2007; Asgarzadeh et al., 2010; Delgadillo et al., 2011)

Plant growth and development are also correlated with S-index values, such as yield (Freddi et al., 2009) and root growth (Dexter, 2004a); however, this relationship is not well defined and the S-index is known to be a better indicator of soil suitability for root growth compared with soil bulk density. Dexter (2004a) and Dexter \& Czyz (2007) proposed that an adequate root growth requires $S$-index values $>0.030$, values between 0.020 and 0.030 promote low root growth and, for $S$ $<0.020$, there is no root development, regardless of the type of soil and plant species.

Plant species have different sensitivities to soil compaction; soybean, for instance, is more tolerant to compaction than corn and cotton (Silva et al., 2006). Thus, soils with limitations to soybean root growth will also pose limitations to less tolerant crops.

Some studies argue the absolute values of the S-index and claim that they are arbitrary and questionable for tropical conditions, since they were determined in soils of European regions (Andrade \& Stone, 2009; Lier, 2014). Andrade \& Stone (2009), studying various soils of the Brazilian Cerrado, suggested S-index $>0.045$ for well-structured soils and S-index $<0.025$ for soils with severe physical degradation, suggesting that the values established by Dexter (2004a) must be validated according to the type of soil and/or crop.

Most studies aiming to prove the efficiency of S-index, as an indicator of soil physical quality, have only related it to soil physical properties, with no direct correlation with plant development, especially with root growth (Kutlu \& Ersahin, 2008; Andrade \& Stone, 2009; Arthur et al., 2011). Therefore, this study tested the hypothesis that the limiting S-index values proposed in the literature can not be used to determine the level of degradation of soils under soybean cultivation in the state of Pará, Brazil. This study aimed to determine limiting values of S-index using soil physical attributes and validate it with soybean root growth, in soils with different textural classes.

\section{Material ANd Methods}

The experiment was carried out in a greenhouse from July to September 2011, at the campus of the Federal Rural University of Amazonia, using a Xantic Kandiudox (USDA, 2010) or Latossolo Amarelo (Brazilian soil classification; EMBRAPA, 2013) of different textural classes collected in the municipalities of Capitão Poço and Paragominas, located in Northeastern Pará (Table 1), the region with the highest soybean production in the state. The climate in the municipality of Capitão Poço is Ami, according to Köppen's classification, with annual rainfall of 2,502 $\mathrm{mm}$, concentrated from February to April. In Capitão Poço, according to the same classification, the climate is Awi, with mean annual rainfall of $1,800 \mathrm{~mm}$ and rains concentrated from December to May. The annual means of temperature and relative air humidity are $26.9^{\circ} \mathrm{C}$ and $80 \%$, respectively, for both municipalities (Bastos et al., 2005).

In each area, approximately $400 \mathrm{~kg}$ of soil were collected from the layer of $0-0.20 \mathrm{~m}$, which were air-dried, pounded to break up clods and sieved through a $0.002 \mathrm{~m}$ grid. Subsamples were collected for analyses of particle-size distribution, organic matter (Table 1), soil fertility (EMBRAPA, 2011) and compaction curve. Particle-size distribution was determined by the pipette method, using $1 \mathrm{M} \mathrm{NaOH}$ as chemical dispersant (Gee \& Bauder, 1986). Soil fertility analysis was used for correction and fertilization, according to the requirements of the soybean crop (Glycine max (L.) Merrill) (Ribeiro et al., 1999).

Soil compaction curves were constructed for each textural class using the normal Proctor test, according to the norm NBR 7182 (ABNT, 1986). This test allows estimating the maximum soil bulk density $\left(\mathrm{Bd}_{\max }\right)$ and its respective moisture, referred to as critical moisture content. $\mathrm{Bd}_{\max }$ is equivalent to the bulk density when the soil reaches its maximum degree of compaction in standard laboratorial test. The fitting equations of compaction curves and the respective values of maximum soil bulk density are shown in Table 2 .

The degree of compaction (DC) was determined in order to facilitate the comparison between the soils of different textural classes, because it is a parameter relative to soil bulk density. DC was determined using the Eq. 1 (Håkansson, 1990):

Table 2. Fitting equations of soil compaction curves for the determination of maximum soil density $\left(\mathrm{Bd}_{\max }\right)$

\begin{tabular}{llcc}
\hline $\begin{array}{c}\text { Soil } \\
\text { (Textural class) }\end{array}$ & \multicolumn{1}{c}{ Equation } & $\mathbf{R}^{2}$ & $\begin{array}{c}\mathbf{B d}_{\max } \\
\left(\mathbf{M g ~ m}^{-3}\right)\end{array}$ \\
Sandy loam & $\mathrm{Bd}=-27.03 \operatorname{\theta g}^{2}+5.93 \theta \mathrm{g}+1.470$ & 0.94 & 1.80 \\
Sandy clay loam & $\mathrm{Bd}=-30.88 \mathrm{\theta g}^{2}+14.9 \theta \mathrm{g}-0.303$ & 0.96 & 1.77 \\
Clay & $\mathrm{Bd}=-24.77 \mathrm{\theta g}^{2}+15.7 \theta \mathrm{g}-1.161$ & 0.98 & 1.52 \\
Clay & $\mathrm{Bd}=-23.15 \mathrm{\theta g}^{2}+5.21 \theta \mathrm{g}+1.477$ & 0.96 & 1.31 \\
\hline
\end{tabular}

$\mathrm{Bd}$ - Soil bulk density; $\theta \mathrm{g}$ - Gravimetric water content

Table 1. Location, particle-size distribution and organic matter content of the four textural classes

\begin{tabular}{|c|c|c|c|c|c|c|c|c|}
\hline \multirow[t]{2}{*}{ Area } & \multirow{2}{*}{ Latitude } & \multirow{2}{*}{ Longitude } & \multirow{2}{*}{ Municipality } & Sand* & Silt & Clay & $0 \mathrm{M}$ & \multirow{2}{*}{ Textural class } \\
\hline & & & & \multicolumn{4}{|c|}{$\left(g_{k g}^{-1}\right)$} & \\
\hline 1 & $1^{0} 44^{\prime} 42^{\prime \prime}$ & $47^{\circ} 03^{\prime} 54^{\prime \prime}$ & Capitão Poço & 756.2 & 68.6 & 175.2 & 25.8 & Sandy loam \\
\hline 2 & $2^{0} 59^{\prime} 42^{\prime \prime}$ & $47^{0} 21^{\prime} 10^{\prime \prime}$ & Paragominas & 663.3 & 129.9 & 206.8 & 37.1 & Sandy clay loam \\
\hline 3 & $1^{0} 44^{\prime} 42 "$ & $47^{\circ} 03^{\prime} 54^{\prime \prime}$ & Capitão Poço & 396.4 & 165.3 & 438.3 & 27.3 & Clay \\
\hline 4 & $2^{\circ} 59^{\prime} 42^{\prime \prime}$ & $47^{0} 21^{\prime} 10^{\prime \prime}$ & Paragominas & 53.2 & 237.0 & 709.8 & 43.4 & Clay \\
\hline
\end{tabular}

*Sand $=2-0.05 \mathrm{~mm} ;$ Silt $=0.05-0.002 \mathrm{~mm}$; Clay $=<0.002 \mathrm{~mm} ; 0 \mathrm{M}=$ Organic matter; $\mathrm{N}=3$ replicates 


$$
\mathrm{DC}=\frac{\mathrm{Bd}}{\mathrm{Bd}_{\max }} \times 100
$$

where:

DC - degree of compaction, \%;

Bd - soil bulk density in each treatment, $\mathrm{Mg} \mathrm{m}^{-3}$; and,

$\mathrm{Bd}_{\max }$ - maximum soil bulk density obtained through the compaction curve, $\mathrm{Mg} \mathrm{m}^{-3}$.

In order to obtain different Bd values for each textural class, preliminary tests of soil compaction were performed for the calibration of the number of impacts, per soil layer, necessary to reach the desired $\mathrm{Bd}$ values. In order to standardize soil compaction, the water content (water content at field capacity, $\psi=-0.01 \mathrm{MPa}$ ) and the mass of soil (based on the volume of soil used in each pot) necessary for each compaction level were previously determined.

The compaction process in the pots consisted of compressing the soil in cylindrical plastic pots with capacity for $0.014 \mathrm{~m}^{3}$ (diameter $=0.239 \mathrm{~m}$; height $=0.290 \mathrm{~m})$, in layers of $0.03 \mathrm{~m}$ until the height of $0.20 \mathrm{~m}$, corresponding to a soil volume of $0.009 \mathrm{~m}^{3}$. The compressing process was performed using a freefalling plunger in the geometric center of a wooden support with diameter of $0.230 \mathrm{~m}$. The height of the fall was $0.60 \mathrm{~m}$ and the plunger had a mass of $7 \mathrm{~kg}$ (Beutler et al., 2004).

Five pots were prepared for each treatment, of which three were used for soybean cultivation and two for the collection of undisturbed soil samples for the determinations of soil water retention curve and S-index. The experiment was set in a completely randomized block design and the treatments consisted of a Bd range for each textural class, representing a situation of soil degradation.

From the Bd considered as optimal for each class, the soil was compacted at about $0.1 \mathrm{Mg} \mathrm{m}^{-3}$ until reaching $\mathrm{Bd}$ values considered as critical. Then, five compaction levels were defined for soils of sandy loam $\left(1.35,1.40,1.49,1.60\right.$ and $\left.1.70 \mathrm{Mg} \mathrm{m}^{-3}\right)$ and sandy clay loam texture $(1.36,1.43,1.50,1.61$ and $1.69 \mathrm{Mg}$ $\left.\mathrm{m}^{-3}\right)$ and three levels for soils of clayey $(1.35,1.41$ and 1.48 $\mathrm{Mg} \mathrm{m}^{-3}$ ) and very clayey texture $\left(1.15,1.24\right.$ and $\left.1.27 \mathrm{Mg} \mathrm{m}^{-3}\right)$, with three replicates in each, totaling 48 pots. For the classes clayey and very clayey, there were only three levels because it was not possible to compact the soils more than the last compaction level.

Four undisturbed samples were collected using steel cylinders (diameter and height $=0.05 \mathrm{~m}$ ) in each pot, considering the 16 compaction levels and two replicates, totaling 128 samples. These samples were collected immediately after the compaction process in the pots, at the beginning of the experiment.

Then, the samples were saturated in the laboratory by gradually increasing the water depth in a tray. After that, the samples were subjected to the matric potentials of -0.003 , -0.006 and $-0.01 \mathrm{MPa}$, on a tension table, and $-0.03 ;-0.06$, $-0.1,-0.3$ and $-0.6 \mathrm{MPa}$, in Richards chambers (Klute, 1986). After equilibrium at each potential, the samples were weighed for the calculation of water content and, at the end, dried in an oven at $105^{\circ} \mathrm{C}$ for $24 \mathrm{~h}$, for the determination of soil bulk density (Blake \& Hartge, 1986).
For the determination of the water content at the potential of -1.5 MPa, a WP4 Dewpoint PotentiaMeter (Decagon') was used, following the procedures described by Costa et al. (2008). Different amounts of distilled water were added in subsamples of $4 \mathrm{~g}$, which were placed in the WP4 sampling recipient; after that, each sample was weighed and placed in an oven for 24 $h$ for the calculation of the water content equivalent to the determined potential.

The fitting of the soil water retention curve (SWRC) was performed through the Eq. 2 (Genuchten, 1980), using the restriction $m=1-1 / n$, proposed by Mualem (1986).

$$
\theta=(\theta \mathrm{s}-\theta \mathrm{r})[1+(\alpha \mathrm{h}) \mathrm{n}]^{-\mathrm{m}}+\theta \mathrm{r}
$$

where:

$\theta \mathrm{s}$ and $\theta \mathrm{r}$ - water content at saturation and residual water content at the potential of $-1.5 \mathrm{MPa}, \mathrm{kg} \mathrm{kg}^{-1}$;

$\mathrm{h}$ - applied potential, MPa; and,

$\alpha, \mathrm{n}$ and $\mathrm{m}$ - parameters of the model.

The derivative of Eq. 2 can be expressed by:

$$
\frac{\mathrm{d} \theta}{\mathrm{d} \ln (\mathrm{h})}=-\mathrm{mn}(\theta \mathrm{s}-\theta \mathrm{r}) \alpha^{\mathrm{n}} \mathrm{h}^{\mathrm{m}}[1+(\alpha \mathrm{h}) \mathrm{n}]^{-\mathrm{m}-1}
$$

Thus, the model for the optimal soil water potential at the SWRC inflection point is given by Eq. 4 :

$$
\mathrm{hi}=\frac{1}{\alpha} \times\left[\frac{1}{\mathrm{~m}}\right]^{\frac{1}{\mathrm{n}}}
$$

Ultimately, the calculation of the S-index, which represents the slope of the curve at its inflection point, was determined by substituting Eq. 4 in the Eq. 3, which results in:

$$
\mathrm{S}=\left[-\mathrm{n} \times(\theta \mathrm{s}-\theta \mathrm{r}) \times\left(1+\frac{1}{\mathrm{~m}}\right)^{-(1+\mathrm{m})}\right]
$$

where:

S - S-index; and,

$\mathrm{m}$ and $\mathrm{n}$ - parameters of the equation of Genuchten (1980).

Pore radius was calculated using the capillarity equation of Vomocil (1965).

In the pots used for soybean cultivation $(\mathrm{N}=48)$, four seeds of the soybean cultivar 'BRS Sambaíba' were planted at the depth of $0.015 \mathrm{~m}$. Seven days after germination, thinning was performed, leaving only two plants per pot. Soil moisture in the pots was maintained close to field capacity $(h=-0.01 \mathrm{MPa})$, based on the daily weighing of the pots and the replenishment of the evapotranspired water.

Sixteen days after sowing, plants were removed from the pots and the roots were washed in running water, using a sieve with a $0.0005 \mathrm{~m}$ grid as a support. After separation and washing, total root length (RL) was determined using the method of Tennant (1975). Relative root length (RLr) was determined using Eq. 6. 


$$
\mathrm{RLr}=\frac{\mathrm{RL}}{\mathrm{RL}_{\max }} \times 100
$$

where:

RLr - relative root length, \%;

$\mathrm{RL}$ - root length for each compaction level (treatment), $\mathrm{m}$; and,

$\mathrm{RL}_{\max }$ - maximum root length of the treatment, $\mathrm{m}$.

The data were analysed using linear regression and analysis of variance for DC, RLr and S-index. Critical soil bulk density and clay content were also correlated through linear regression, all using a 0.05 significance level by $\mathrm{F}$ test. All the analyses were performed using the statistical program SAS Institute (2002).

\section{Results AND Discussion}

The data of degree of compaction (DC), SWRC fitting parameters and S-index are shown in Table 3. With the increase in DC, there was a significant decrease in $\theta$ s in the classes sandy loam ( $17 \%$ of clay) and sandy clay loam ( $21 \%$ of clay), with no variation of $\theta \mathrm{r}$ and small variation for the parameters $\alpha$ and $n$, which are responsible for the shape of the curve. Consequently, the change in the SWRC slope at the inflection point (S-index) occurred at the fourth compaction level for the sandy loam class and at the third level for the sandy clay loam. Thus, the soil with higher clay content $(21 \%)$ responded faster to the variation in soil compaction (Table 3 ).

S-index increased with the increment in DC only in soils with $17 \%$ and $21 \%$ of clay; in the others, S-index did not vary with DC (Table 3). Moncada et al. (2015), studying the effects of S-index in soils of medium texture (9.7 to $42.3 \%$ of clay) of tropical and temperate regions, suggested that the S-index value must be established for each textural class, instead of using only one value. This is supported by Garg et al. (2009), who observed decrease in S-index with the increase in the mean content of clay until $20-30 \%$ in Indian soils (6-81\% of clay); then, the index gradually increased and sharply decreased when the mean clay content exceeded 45\%. Moncada et al. (2014) observed that $33 \%$ was the optimal clay content, above which the structural quality of the soil decreases.

In clayey ( $44 \%$ of clay) and very clayey ( $71 \%$ of clay) soils, the increase of DC did not cause changes in $\theta$ s or in the other parameters; therefore, there was no change in the SWRC slope at the inflection point (S-index) (Table 3). For this case, the physical degradation of the soil, imposed by the increase in DC, is not consistent with the change in SWRC shape, which indicates that, for the applied DC, the soils were already compacted, although the mean value of the $S$-index was equal to 0.06 for the clayey soil and 0.047 for the very clayey soil. According to Dexter (2004a), the peak of the S-index in soils with clay contents between 30 and $50 \%$ can be associated with the increase in soil microstructure.

It is important to point out that the studies estimating S-index values (Dexter, 2004a; Andrade \& Stone, 2009) used soils with clay contents lower than $65 \%$; thus, the use of these values to estimate degradation in very clayey soils with $71 \%$ of clay is considered as arbitrary.

For a comparison of S-index between different studies, Dexter (2004a,b) established a few criteria: (i) the water content was expressed gravimetrically $\left(\mathrm{kg} \mathrm{kg}^{-1}\right)$ for the calculation of the parameters of the equation of Genuchten (1980); (ii) the restriction $m=1-1 / n$ was used; and (iii) $\theta \mathrm{r}$ was defined as equal to zero. This last criterion was not used in the present study, because the soils had high clay contents, which favored water retention at the potential of $-1.5 \mathrm{MPa}$.

Figure 1 shows the derivative of Eq. 3 with respect to the pore radius, i.e., the changes in the shape of the curve of pore size distribution as a function of DC and soil texture. The $S$-index value coincides with the part of the curve in which the volume of pores increase sharply with the decrease in the

Table 3. Mean degree of compaction (DC) for each textural class and the respective means and standard errors for the fitting parameters of the soil water retention curve for four textural classes

\begin{tabular}{|c|c|c|c|c|c|c|}
\hline $\begin{array}{l}\text { DC } \\
(\%)\end{array}$ & $\begin{array}{l}\text { Number } \\
\text { of samples }\end{array}$ & $\begin{array}{c}\theta \mathrm{S} \\
\left(\mathrm{kg} \mathrm{kg}^{-1}\right)\end{array}$ & $\begin{array}{c}\text { Or } \\
\left(\mathrm{kg} \mathrm{kg}^{-1}\right)\end{array}$ & $\begin{array}{c}\alpha \\
\left(\mathrm{hPa}^{-1}\right)\end{array}$ & n & S-index \\
\hline \multicolumn{7}{|c|}{ Sandy loam } \\
\hline 75 & 8 & $0.3247 a \pm 0.005$ & $0.0812 \mathrm{a} \pm 0.002$ & $0.0108 \mathrm{a} \pm 0.000$ & $2.3177 \mathrm{a} \pm 0.037$ & $0.115 a$ \\
\hline 78 & 8 & $0.2849 b \pm 0.003$ & $0.0757 \mathrm{a} \pm 0.002$ & $0.0090 a b \pm 0.000$ & $2.4398 \mathrm{a} \pm 0.077$ & $0.105 a$ \\
\hline 83 & 8 & $0.2737 b \pm 0.005$ & $0.0875 a \pm 0.004$ & $0.0079 b \pm 0.000$ & $2.4845 a \pm 0.179$ & $0.094 \mathrm{a}$ \\
\hline 89 & 6 & $0.2387 c \pm 0.008$ & $0.0904 a \pm 0.008$ & $0.0076 b \pm 0.000$ & $2.3956 a \pm 0.216$ & $0.070 \mathrm{~b}$ \\
\hline 95 & 3 & $0.2017 d \pm 0.016$ & $0.0965 a \pm 0.003$ & $0.0068 b \pm 0.000$ & $2.7363 \mathrm{a} \pm 0.217$ & $0.063 \mathrm{~b}$ \\
\hline \multicolumn{7}{|c|}{ Sandy clay loam } \\
\hline 77 & 8 & $0.3496 \mathrm{a} \pm 0.011$ & $0.1217 \mathrm{a} \pm 0.005$ & $0.0169 a \pm 0.001$ & $2.5728 \mathrm{a} \pm 0.120$ & $0.121 \mathrm{a}$ \\
\hline 81 & 6 & $0.3218 a \pm 0.007$ & $0.1126 \mathrm{a} \pm 0.003$ & $0.0148 \mathrm{a} \pm 0.000$ & $2.3500 a b \pm 0.080$ & $0.100 \mathrm{a}$ \\
\hline 85 & 8 & $0.2809 b \pm 0.010$ & $0.1106 a \pm 0.010$ & $0.0132 a \pm 0.000$ & $2.2503 a b \pm 0.088$ & $0.076 b$ \\
\hline 91 & 3 & $0.2090 \mathrm{c} \pm 0.011$ & $0.1209 a \pm 0.012$ & $0.0078 b \pm 0.002$ & $2.0567 a b \pm 0.110$ & $0.035 \mathrm{c}$ \\
\hline 96 & 3 & $0.1891 c \pm 0.003$ & $0.1006 \mathrm{a} \pm 0.013$ & $0.0107 a \pm 0.000$ & $1.7512 b \pm 0.213$ & $0.027 \mathrm{C}$ \\
\hline \multicolumn{7}{|c|}{ Clayey } \\
\hline 89 & 5 & $0.3644 a \pm 0.016$ & $0.2158 a \pm 0.007$ & $0.0169 a \pm 0.002$ & $2.3852 \mathrm{a} \pm 0.131$ & $0.072 \mathrm{a}$ \\
\hline 93 & 3 & $0.3496 a \pm 0.018$ & $0.2267 \mathrm{a} \pm 0.011$ & $0.0183 a \pm 0.000$ & $2.2859 a \pm 0.294$ & $0.055 \mathrm{a}$ \\
\hline 97 & 3 & $0.3295 a \pm 0.019$ & $0.2129 a \pm 0.010$ & $0.0147 a \pm 0.009$ & $2.2805 a \pm 0.106$ & $0.053 \mathrm{a}$ \\
\hline \multicolumn{7}{|c|}{ Very clayey } \\
\hline 88 & 6 & $0.3816 b \pm 0.000$ & $0.2250 a \pm 0.002$ & $0.0011 \mathrm{a} \pm 0.000$ & $1.7948 a \pm 0.064$ & $0.051 \mathrm{a}$ \\
\hline 94 & 7 & $0.4207 a \pm 0.005$ & $0.2236 a \pm 0.014$ & $0.0040 a \pm 0.001$ & $1.5339 b \pm 0.026$ & $0.049 \mathrm{a}$ \\
\hline 97 & 6 & $0.3982 b \pm 0.007$ & $0.2011 \mathrm{a} \pm 0.005$ & $0.0023 a \pm 0.000$ & $1.4661 b \pm 0.044$ & $0.043 \mathrm{a}$ \\
\hline
\end{tabular}

$\theta \mathrm{S}$ - Soil water content at saturation; $\theta \mathrm{r}$ - Residual water content at the potential of $-1.5 \mathrm{MPa} ; \alpha$ and $n$ - model parameters. All the values were followed by the \pm standard error. 

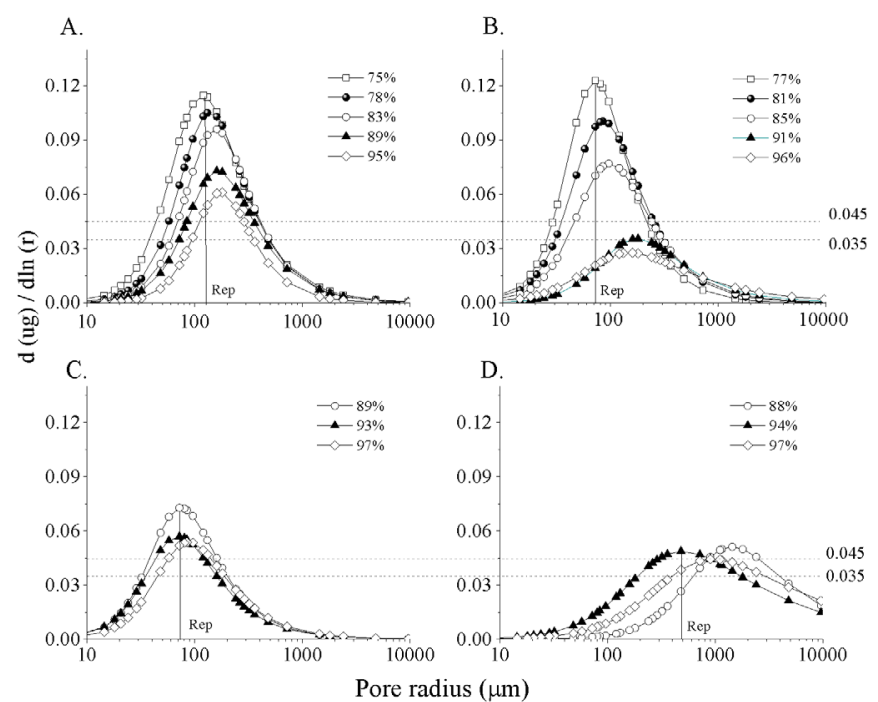

Dashed lines represent the critical limits of the S-index proposed by Dexter (2004) (0.035) and Andrade \& Stone (2009) (0.045), and Rep is the equivalent pore radius

Figure 1. Pore size distribution determined by Eq. 3, as a function of pore radius, for each compaction level and textural class: sandy loam (A); sandy clay loam (B); clayey (C) and very clayey (D)

radius, representing the point of the curve where most changes occur during the process of compaction (Startsev \& McNabb, 2001), i.e., the higher this value, the lower the physical damage on soil structure.

The peak of the derivative corresponds to the equivalent pore radius (Rep) or to the optimal water potential in the soil at the inflection point (hi) (Figure 1). Structural pores correspond to the pores emptied between soil saturation $(h=0)$ and the inflection point $(\mathrm{h}=\mathrm{hi}=\mathrm{Rep})$. The data show that changes in SWRC shape within the same textural class are determined by $\theta$ s and not by the parameters $n$ and $\alpha$, since they do not vary with the increase of DC and the emptying of the pores does not occur in the same way for all the soils. In other words, in Figure $1 \mathrm{~B}$, the emptying becomes slower from the $\mathrm{DC}=91 \%$ on, and in the Figure $1 \mathrm{C}$ and $1 \mathrm{D}$, there was no significant decrease in the S-index with the increase in DC.

In the soil with sandy loam texture, the position of Rep varied from $12.3 \mu \mathrm{m}$ for the DC of $75 \%$ to $17.4 \mu \mathrm{m}$ for $\mathrm{DC}=95 \%$ (Figure 1A). In the sandy clay loam class, the Rep varied from 7.25 to $18.5 \mu \mathrm{m}$ between the analysed DC values (Figure $1 \mathrm{~B}$ ); in the other classes, S-index and Rep did not show significant difference between the curves, remaining unchanged even with the increase in DC. In the very clayey class, DC changed the pores with larger radius and closer to saturation (Figure 1D). In the literature, the radius limit between the textural porosity (or matrix) and the structural porosity has been proposed as 25 $\mu \mathrm{m}$ (Lal \& Shukla, 2004; Pagliai \& Vignozzi, 2002). Reynolds et al. (2009) observed radius values between 30 and $70 \mu \mathrm{m}$ for soils grouped as good, which are positively correlated with the limiting values of the S-index established by Dexter (2004a). Considering these limits, none of the studied soils would be classified as good for management; however, these data confirm the alteration in structural porosity with the increase in DC and indicate that it occurs in different ways for each textural class.

In the comparison among all the classes, only the very clayey texture (Figure 1D) did not follow the same pattern of compaction of the others, i.e., the S-index value did not decrease with the increase in soil bulk density and/or DC. However, it confirms the data of Dexter \& Czyz (2007), who claim that soils with higher clay contents have lower S-index for the same value of soil density and/or DC. In other words, at the DC of $97 \%$, the S-index was lower in the very clayey soil (71\% of clay) compared with the clayey soil ( $44 \%$ of clay) (Figure $1 C)$, which highlights that, when pedotransfer functions are used in soils with different textural classes, the $\mathrm{S}$-index value can be under or overestimated.

In the sandy loam class, the S-index was high (0.063), even at a DC of $95 \%$ (Figure 1A), which can be related to the higher percentage of the sand fraction. The increase in sand fraction promotes the decrease in microstructure, caused by the absence of inter-aggregate spaces, which decreases the S-index value (Reynoldy et al., 2009). According to Kutlu \& Ersahin (2008), from $40 \%$ of sand on, the S-index value increases due to drastic changes in pore size distribution, as observed in Figure 1A. Therefore, the S-index shows a poor performance in the characterization of quality in soils with higher sand contents, which is consistent with Arthur et al. (2011).

In addition, in Figure $1 \mathrm{~A}$ and $1 \mathrm{C}$, for all the compaction levels, the S-index values are above those proposed in the literature (0.045 and 0.035$)$ to separate soils considered as "good" from those with "poor" soil structure. In Figure 1B, following the same reasoning, the soil will only be considered as "poor" when the DC is higher than $91 \%$.

The relationship between S-index and DC was inversely proportional and highly significant for the analysed textural classes (Figure 2). Soils with sandy loam and sandy clay loam textures have Pearson's correlation coefficients ranging from medium to high ( $r=-0.65$ and -0.91$)$, respectively (Figure 2A, 2B). These results are confirmed by Andrade \& Stone (2009), who observed similar coefficients of determination $\left(R^{2}\right)$ for this relationship for the sandy loam texture and lower coefficients for the sandy clay loam texture. Dexter (2004a) observed $\mathrm{R}^{2}=0.74$ using soils with $27 \%$ of clay. Kutlu \& Ersahin (2008) reported a significant relationship $\left(\mathrm{R}^{2}=0.52, \mathrm{p}<0.0002\right)$

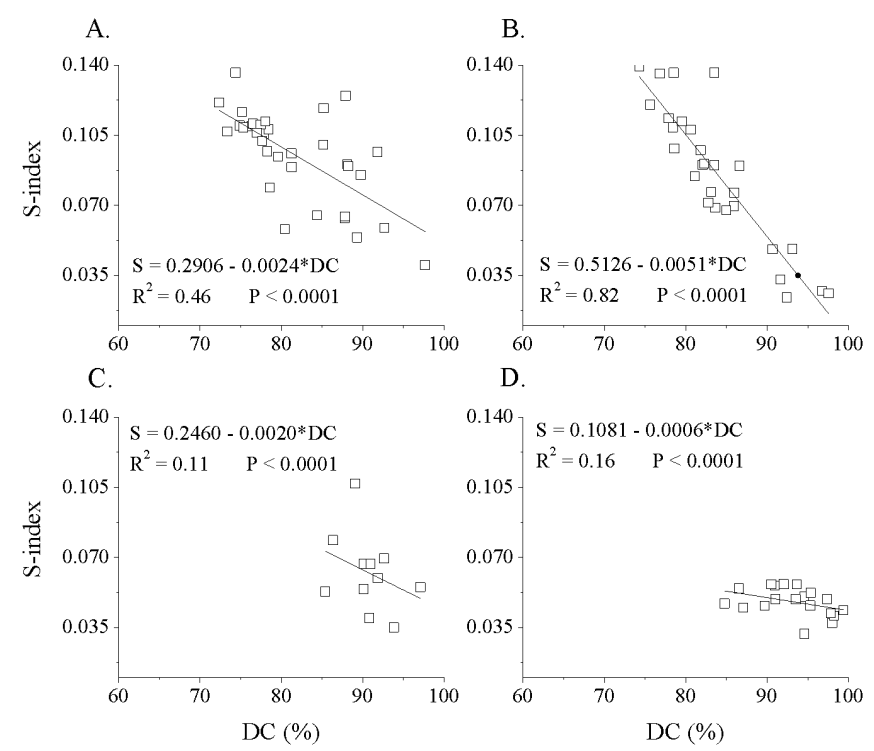

Figure 2. Relationship between degree of compaction (DC) and S-index, for the textural classes sandy loam (A), sandy clay loam (B), clayey (C) and very clayey (D) 
between soil bulk density and S-index for soils with 22, 34 and $44 \%$ of clay. Therefore, soil compaction decreased total porosity and changed pore size distribution, reducing the values of the S-index, especially for the sandy clay loam class. The low coefficient of determination $\left(\mathrm{R}^{2}\right)$ can be explained by the large amount of data and number of replicates used.

In the classes with more than $40 \%$ of clay (Figure 2C, 2D), the coefficient of determination was extremely low, because the S-index did not vary significantly with the increase in DC (Table 3). Thus, reviewing the concepts of the S-index, it can be inferred that: (i) the index value does not decrease gradually with the increase in DC for all the textural classes and (ii) in soils with clay contents $>40 \%$, the S-index does not vary with DC.

The relative root length (RLr) decreased with the reduction in S-index values (Figure 3), except for the soil with very clayey texture, in which root growth did not show relationship with the S-index (Figure 3D). This behavior evidences the sensitivity of this indicator of soil physical quality to changes in root development, as indicated by Dexter (2004a).

Based on the equations of Figure 2, it is possible to calculate the S-index corresponding to the maximum DC obtained for each textural class. Substituting these values in the equations of Figure 3, there is a reduction of 39\% in RL for the sandy loam textural class, $49 \%$ for sandy clay loam, 56\% for clayey and $58 \%$ for very clayey. For a RL reduction of $50 \%$, a value considered as critical (Dexter, 1987), the S-index values are equivalent to 0.037 for the sandy loam class, 0.020 for sandy clay loam and 0.056 for clayey. These data show great differences between S-index values to separate "good" soils from those considered as "poor", in the analysed textural classes, and that there is not a direct relationship between the increase in clay content and the S-index value. However, it confirms that higher values of S-index are associated with better root development.

Dexter (2004a), using data of Jones (1983), observed the following limiting values of $\mathrm{S}$-index: $\mathrm{S}=0.035$ (limit between
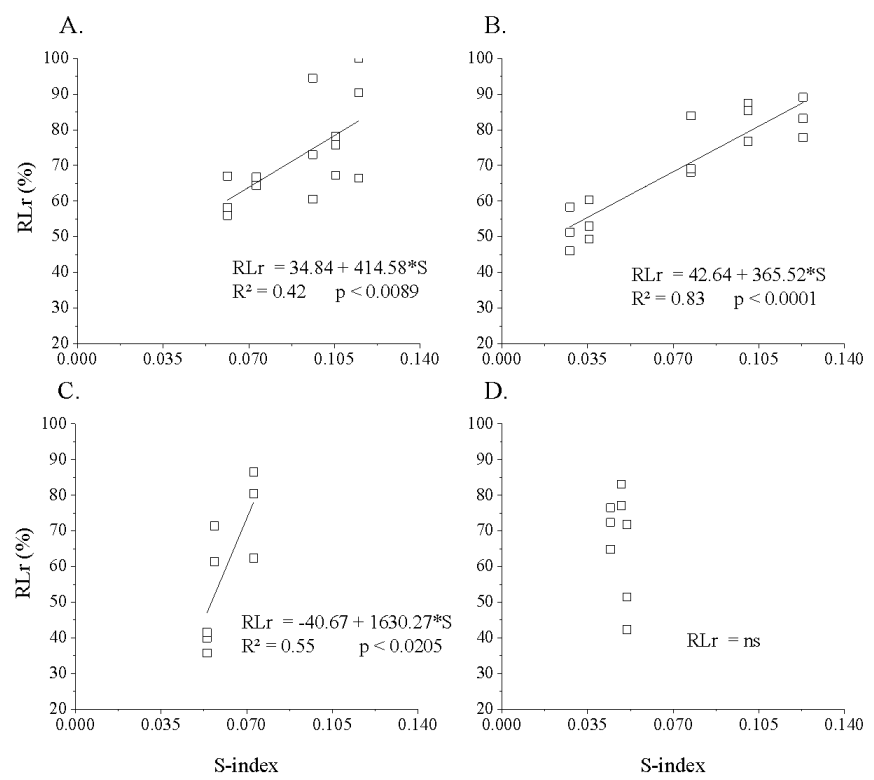

ns - not significant

Figure 3. Relationship between relative root length (RLr) of soybean and S-index for the textural classes sandy loam (A), sandy clay loam (B), clayey (C) and very clayey (D) soils with "good" and "poor" physical quality) when root growth was reduced to $50 \%$ of its maximum, and $\mathrm{S}=0.020$ when root growth was reduced to $30 \%$ of its maximum. These values were based on results of root growth of plants from various species in different types of soil. Jones (1983) concluded that the values of soil bulk density that defined the limits between the conditions without root growth, with root growth and limited root growth depended on soil clay content. Dexter (2004a) observed that these limits corresponded to the experimental error; thus, constant values of the S-index. Andrade \& Stone (2009) established values of $0.045>$ S-index $<0.025$ as the limit of separation between soils with "good" and "poor" physical quality, in the Cerrado, based on other physical properties, such as macroporosity.

As observed in Figure 3, it was not possible to calculate the lower limit of the S-index for the $\mathrm{RL}=30 \%$, because S-index values were close to zero in soils with sandy loam (Figure $3 \mathrm{~A}$ ) and sandy clay loam (Figure 3B) textures. In the soil with clayey texture (Figure $3 \mathrm{C}$ ), the limits of $\mathrm{RL}=50$ and $30 \%$ were 0.056 $>$ S-index $<0.043$.

The $\mathrm{RL}=30 \%$ for soybean can not be determined, because the crop has a taproot system that is very aggressive in compacted layers, differing from the crops used by Jones (1983), such as: cotton, corn and sugarcane. For the reduction of $50 \%$ in soybean RL, it is possible to deduce that, at this point, other more sensitive crops suffer the effects of soil compaction before soybean does; therefore, the value of the estimated S-index is much lower. In addition, it is important to point out that, in the estimate of the S-index proposed by Dexter (2004a), different soil classes and crops were used.

For the soil with very clayey texture, the increase in soil density did not alter significantly S-index values and there was no correlation with RLr; thus, no critical value of RL could be attributed to soybean for this type of soil (Figure 3D). The higher content of organic matter in this soil can be one explanation for the increase and the formation of pores and microstructure in the soil (Kutlu \& Ersahin, 2008), justifying the high value of S-index (Dexter, 2004a) and favoring RL. However, this did not occur in Figure 3D, because there was RLr of only $40 \%$ for DC $=97 \%$, evidencing that other factors can influence root growth, such as lack of oxygen for this DC or other chemical factors not discussed here.

Based on the critical S-index values of 0.037, 0.020 and 0.056 , for soils with sandy loam, sandy clay loam and clayey textures, respectively, and on the DC at which those values were obtained, it is possible to determine, according to Eq. 1 , the following values of critical soil bulk density (Bdc): 1.8, 1.72 and $1.44 \mathrm{Mg} \mathrm{m}^{-3}$, respectively. This shows an inverse relationship of Bdc with soil clay content and confirms the results of Jones (1983).

Based on the Bdc values found for each soil, the Bd limit at which root growth is decreased by half $(\mathrm{RL}=50 \%)$ was obtained through the linear fitting between Bdc and clay content (Figure 4). For these data, a line that limits soybean root growth in a severely affected area and in an area where root growth is favored was established; however, this relationship is not adequate for sandy soils with sand contents $<17 \%$ or very clayey soils. 


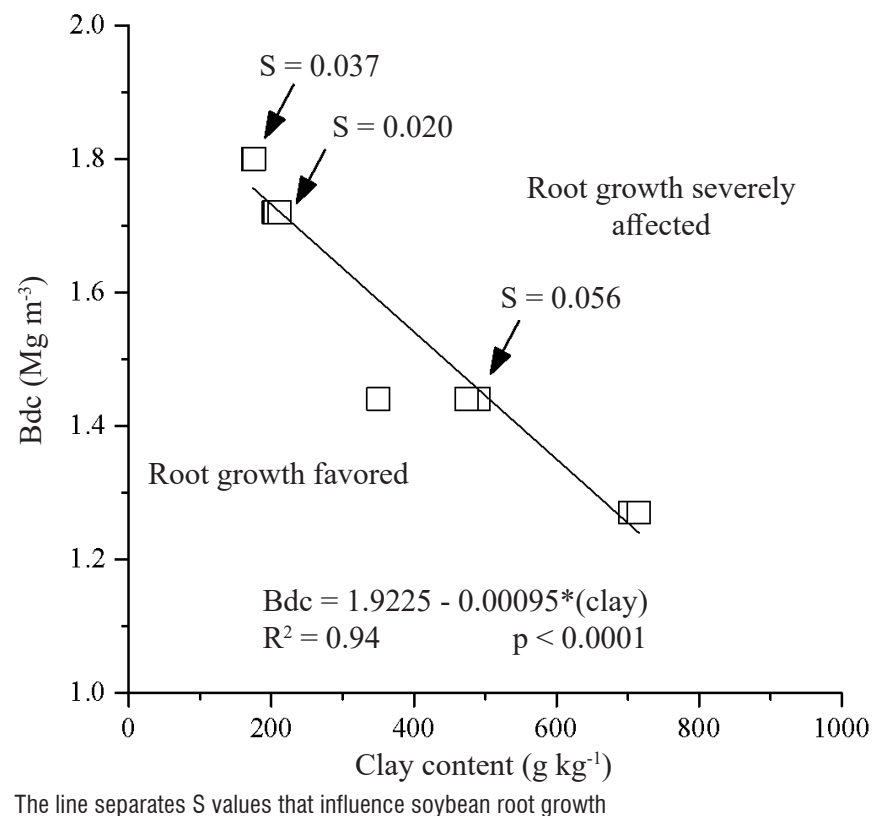

Figure 4. Critical soil bulk density (Bdc) as a function of clay content

The obtained critical limit of Bdc (Figure 4) was higher than the limits established by Jones (1983) and Dexter (2004a). This can be associated with different sensitivities to soil compaction among plant species, since soybean is more tolerant than certain crops, such as corn and cotton (Silva et al., 2006), which justifies higher Bdc values (Figure 4).

The equations proposed by Jones (1983) were developed using soils of North America, and Dexter (2004a) used soils from Western Europe. Therefore, the peculiarities of the tropical soils used in the present study are probably associated with the divergences. In addition, in Figure 4, Bdc values are not associated with only one S-index value, as proposed by Dexter (2004a), in which root growth is reduced by half when S-index $=0.030$.

In general, it can be considered that S-index has limitations when associated with DC and RL, especially in clayey and very clayey soils. In addition, the use of only one parameter to evaluate management conditions and soil degradation must be performed with caution, observing the correspondence of the generated parameters with the data to be tested.

\section{Conclusions}

1. The limiting values of the S-index proposed in the literature can not be used to determine the level of degradation of soils under soybean cultivation in the state of Pará, confirming the tested hypothesis.

2. The values of S-index $=0.037,0.020$ and 0.056 , which were limiting for soybean root growth, varied according to the analysed textural classes: sandy loam, sandy clay loam and clay, respectively.

3. S-index does not apply to soils with clay content $>71 \%$, because it does not vary with the degree of compaction or the root growth of the analyzed crop.

4. The critical soil bulk density shows good relationship with S-index and can be used to analyse crop root growth according to soil textural class.

\section{Acknowledgments}

To the DAAD (Brazil-Germany Academic Exchange Service), for the scholarship, and to the Federal Rural University of Amazônia.

\section{Literature Cited}

ABNT - Associação Brasileira de Normas Técnicas. NBR 7182/86. Solo: Ensaio de compactação. Rio de janeiro: ABNT, 1986. 10p.

Andrade, R. S.; Stone, F. Índice S como indicador da qualidade física de solos do cerrado brasileiro. Revista Brasileira de Engenharia Agrícola e Ambiental, v.13, p.382-388, 2009. http://dx.doi. org/10.1590/S1415-43662009000400003

Arthur, E.; Cornelis, W. M.; Vermang, J.; De Rocker, E. Amending a loamy sand with three compost types: impact on soil quality. Soil Use and Management, v.27, p.116-123, 2011. http://dx.doi. org/10.1111/j.1475-2743.2010.00319.x

Asgarzadeh, H.; Mosaddeghi, M. R.; Mahboubi, A.A.; Nosrati, A.; Dexter, A.R. Soil water availability for plants as quantified by conventional available water, least limiting water range and integral water capacity. Plant Soil, v.335, p.229-244, 2010. http:// dx.doi.org/10.1007/s11104-010-0410-6

Bastos, T. X.; Pacheco, N. A.; Figueirêdo, R. de O.; Silva, G. de F. G. da. Características agroclimáticas da Município de Paragominas. Belém: Embrapa Amazônia Oriental, 2005.21p. Documentos, 228

Beutler, A. N.; Centurion, J. F.; Silva, A. P. Intervalo hídrico ótimo e a produção de soja e arroz em dois latossolos. Brazilian Journal of Irrigation and Drainage. v.9, p.181-192, 2004.

Blake, G. R.; Hartge, K. H. Bulk density. In: Klute, A. Methods of soil analysis: Physical and mineralogical methods. 2.ed. Madison: American Society of Agronomy/SSSA, 1986. Part 1, p.363-375.

Costa, W. A.; Oliveira, C. A. da S.; Kato, E. Modelos de ajuste e métodos para a determinação da curva de retenção de água de um Latossolo-Vermelho-Amarelo. Revista Brasileira de Ciência do Solo, v.32, p.515-523, 2008. http://dx.doi.org/10.1590/S010006832008000200006

Delgadillo, L. F.; Fedick, S. L.; Solleiro-Rebolledo, E.; PalaciosMayorga, S.; Ortega-larrocea, P.; Sedov, S.; Osuna-Ceja, S. A sustainable system of a traditional precision agriculture in a maya homegarden: Soil quality aspects. Soil \& Tillage Research, v.113, p.112-120, 2011. http://dx.doi.org/10.1016/j.still.2011.03.001

Dexter, A. R. Mechanics of root growth. Plant and soil, v.98, p.303312, 1987. http://dx.doi.org/10.1007/BF02378351

Dexter, A. R.; Soil physical quality: Part I. Theory, effects of soil texture, density, and organic matter, and effects on root growth. Geoderma, v.120, p.201-214, 2004a. http://dx.doi.org/10.1016/j. geoderma.2003.09.004

Dexter, A. R.; Soil physical quality: Part II. Friability, tillage, tilth and hard-setting. Geoderma, v.120, p.215-225, 2004b. http://dx.doi. org/10.1016/j.geoderma.2003.09.005

Dexter, A. R.; Czyz, E. A.; Applications of s-theory in the study of soil physical degradation and its consequences. Land Degradation \& Development, v.18, p.369-381, 2007. http://dx.doi.org/10.1002/ ldr.779

EMBRAPA - Empresa Brasileira de Pesquisa Agropecuária. Manual de métodos de análise de solo. 2.ed. Centro nacional de pesquisa de solos, Rio de Janeiro: EMBRAPA, 2011. 230p. 
EMBRAPA - Empresa Brasileira de Pesquisa Agropecuária. Sistema brasileiro de classificação de solos. 3.ed. Brasília, 2013. 353p.

Freddi, O. S.; Centurion, J. F.; Duarte, A. P.; Leonel, C. L. Compactação do solo e produção de cultivares de milho em Latossolo Vermelho I - Características de planta, solo e índice S. Revista Brasileira de Ciência do Solo, v.33, p.793-803, 2009. http://dx.doi.org/10.1590/ S0100-06832009000400005

Garg, R. N.; Mazumdar, S. P.; Chattaraj, S.; Chakraborty , D.; Singh, R.; Kumari, M.; Assessment of soil physical conditions: Evaluation of a single value index. Journal of Agricultural Physics, v.9, p. 9-19, 2009.

Gee, G. W.; Bauder, J. W. Particle-size analysis. In: Klute, A. (ed.). Methods of soil analysis. Parte1, 2.ed. Madison: American Society of Agronomy/SSSA. 1986. p.383-411.

Genuchten, M. T. van. A closed-form equation for predicting the hydraulic conductivity of unsaturated soils. Soil Science Society of America Journal, v.44, p.892-898, 1980. http://dx.doi.org/10.2136/ sssaj1980.03615995004400050002x

Håkansson, I. A method for characterizing the state of compactness of the plough layer. Soil Tillage Research, v.16, p.105-120, 1990. http://dx.doi.org/10.1016/0167-1987(90)90024-8

Jones, C. A. Effect of soil texture on critical bulk densities for root growth. Soil Science Society of America Journal, v.47, p.1208-1211, 1983. http://dx.doi.org/10.2136/sssaj1983.03615995004700060029x

Klute, A. Water retention: Laboratory methods. In 'methods of soilanalysis: physical and mineralogical methods'. Klute, A. (ed.) Madison: American Society of Agronomy, Soil Science Society of America: 1986, p.635-660.

Kutlu, T.; Ersahin, S. Evaluation of soil physical quality in mollic ustifluvent typic ustifluvent andtypic ustorthent using dexter's s-theory. Journal of Food Agriculture \& Environment, v.6, p.450455, 2008.

Lal, R.; Shukla, M. K. Principles of soil physics. Boca Raton: CRC Press. 2004. 697p.

Lier, Q. de J. van. Revisiting the s-index for soil physical quality and its use in brazil. Revista Brasileira de Ciência do Solo, v.38, p.110, 2014. http://dx.doi.org/10.1590/S0100-06832014000100001
Moncada, M. P.; Ball, B. C.; Gabriels, D.; Lobo, D.; Cornelis, W. M. Evaluation of soil physical quality index $\mathrm{S}$ for some tropical and temperate medium-textured Soils. Soil Science Society of America Journal. v.79, p. 9-19, 2015. http://dx.doi.org/10.2136/sssaj2014.06.0259

Moncada, M. P.; Gabriels, D.; Cornelis, W. M.; Data-driven analysis of soil quality indicators using limited data. Geoderma, v.235/236, p.271-278, 2014. http://dx.doi.org/10.1016/j.geoderma.2014.07.014

Mualem, Y. Hydraulic conductivity of unsaturated soils: Prediction and formulas. In: Klute, A., ed. Methods of soil analysis: Physical and mineralogical methods. 2.ed. Madison, America Society of Agronomy: 1986, p.799-823.

Pagliai, M.; Vignozzi, N.The soil pore system as an indicator of soil quality. Advances in GeoEcology, v.35, p.69-80, 2002.

Reynolds, W. D.; Drury, C. F.; Tan, C. S.; Fox, C. A.; Yang, X. M. Use of indicators and pore volume-function characteristics to quantify soil physical quality. Geoderma, v.152, p.252-263, 2009. http:// dx.doi.org/10.1016/j.geoderma.2009.06.009

Ribeiro, A. C.; Guimarães, P. T. G.; Alvarez V., V. H. Recomendações para uso de corretivos e fertilizantes em Minas Merais - $5^{\text {a }}$ Aproximação, Comissão de Fertilidade do Estado de Minas Gerais, Viçosa: SBCS, 1999. 359p.

SAS Institute: SAS: User's guide: Statistics. 9.ed. Cary: SAS Institute, 2002. 943p.

Silva, G. J.; Maia, J. C. D.; Bianchini, A. Shoot growth of plants under subsurface irrigation and four degrees of soil compaction. Revista Brasileira de Ciência do Solo, v.30, p.31-40, 2006.

Startsev, A. D.; McNabb, D. H. Skidder traffic effects on water retention, pore-size distribution, and van Genuchten parameters of boreal forest soils. Soil Science Society of America Journal, v.65, p.224-231, 2001. http://dx.doi.org/10.2136/sssaj2001.651224x

Tennant, D. A. A test of a modified line intersect method of estimating root length. Journal of Ecology. v.63, p.995-1001, 1975. http:// dx.doi.org/10.2307/2258617

USDA - United States Department of Agriculture. Keys to soil taxonomy. Washington: USDA. 2010. 344p.

Vomocil, J. A. Porosity. In: Black, C. A. (ed.). Methods of soil analysis, Part1. Physical and Mineralogical Properties. Madison: American Society of Agronomy, 1965. p.299-314. 